\title{
Growth and Yield of Soybean on Various Types and Concentrations of Liquid Organic Fertilizer in Ultisols
}

\author{
Hesti Pujiwati ${ }^{1}$, Nanik Setyowati ${ }^{1}$, Desi Dwi Wahyuni ${ }^{2}$, Zainal Muktamar ${ }^{3}$ \\ ${ }^{1}$ Department of Crop Production, Faculty of Agriculture, University of Bengkulu, Bengkulu, \\ Indonesia \\ ${ }^{2}$ Agroecotechnology Study Program, Faculty of Agriculture, University of Bengkulu, Bengkulu, \\ Indonesia \\ ${ }^{3}$ Department of Soil Science, Faculty of Agriculture, University of Bengkulu, Bengkulu, Indonesia \\ * Corresponding author \\ Email: nsetyowati@unib.ac.id
}

\begin{abstract}
The application of a wed-based liquid organic fertilizer can increase the production of black soybeans (Glycine Max L. Merril). The study aimed to identify the best source and dose of liquid organic fertilizer (LOF) for black soybean growth and yield. The researchers used a threetimes-repeated Completely Randomized Design (CRD) using a factorial layout. The first factor was the source of LOF, which included Siam weed (Chromolaena odorata, L.), Goat weed (Ageratum conyzoides L.), and yellow creeping daisy (Wedelia trilobata L.). The second factor was the concentration of weed-based LOF, consisted of water (control treatment); $12 \mathrm{ml} / \mathrm{L} ; 16$ $\mathrm{ml} / \mathrm{L} ; 20 \mathrm{ml} / \mathrm{L}$. The results of the study show, weed-based LOF, namely LOF Yellow creeping daisy, Goat weed, and Siam weed, resulted in no significant difference in the growth and yield of the black soybean. Except for the variables of root fresh weight and number of pods per plant, the variation in concentration of weed-based liquid organic fertilizer had no significant effect on plant growth and yield.
\end{abstract}

Keywords: black soybean; LOF; liquid organic fertilizer; glycine max

\section{Introduction}

Black soybean (Glycine Max L. Merril) has a high economic value and may be grown on a large scale in Indonesia. The need for soybeans continues to increase in line with the increasing population and demand for soybean products. Increasing demand for this commodity needs an increase in land extensification. Ultisols is commonly used for black soybean cultivation to meet the community's needs and industry consumption.

In Indonesia, Ultisols is widespread, particularly in wet land of Sumatera, Kalimantan, and Papua. Ultisols is acid soil that is widely distributed in Bengkulu Province, Indonesia. Although Ultisols has potential for soybean development, the utilization of the soil has problems due to low soil $\mathrm{pH}$, low organic matter content, and low P nutrient content. Application of organic matter to the acid soil increases soybean yield (Sujana \& Pura, 2015).

A way to provide nutrients $\mathrm{N}, \mathrm{P}, \mathrm{K}$ in black soybean in Ultisols is to apply weed-based Liquid Organic Fertilizer (LOF) to increase soybean growth and yield. Siam weed (Chromolaena odorata, L) has potential as a source of LOF since Siam weed produces high biomass and nutrient content such as N: $0.145 \%, \mathrm{P}: 2.07 \%$, and $\mathrm{K}: 0.45 \%$. 
Siam weed is a good source of organic fertilizer because of its high nutrient content. The application of organic Siam weed fertilizer increased the growth and yield of lettuce (Duaja, 2012). A $30 \%$ concentration of Siam weed-based LOF stimulates the growth of red spinach (Bete, 2018). Besides Siam weed, Goat weed (Ageratum conyzoides L.) and yellow creeping daisy (Wedelia trilobata L.) weeds are also potential sources of LOF. Kilkoda et al. (2015) reported, Goat weed LOF affects the weight of 100 soybean seeds. The application of weed-based LOF affects sweet corn plants (Raksun, 2014). According to Setyowati et al. (2009), Yellow creeping daisy bokashi can replace $\mathrm{N}$ nutrients. Yellow creeping daisy organic fertilizer application also affects the growth and yield of mustard greens (Setyowati et al., 2008).

The LOF effect on crop productivity is dependent on a variety of parameters, including the source of the LOF material, concentration, target plant, and others. Moringa liquid organic fertilizer at $20 \mathrm{ml} / \mathrm{L}$ had a significant effect on plant height, the number of leaves, and the number of tillers on upland red rice (Nasira et al., 2021). Puteri et al. (2021) reported that plant height, number of leaves, stem diameter, ear weight, and ear length of sweet corn were not affected by Tithonia (Tithonia diversifolia) LOF. Combining the planting system and the Gliricidia leaves + banana weevil LOF resulted in higher rice yields than Gliricidia tree leaves or banana weevils LOF (Mollah et al., 2021). Plant height, number of leaves, and flowering time were higher in the $15 \mathrm{ml}$ $\mathrm{L}^{-1}$ liquid fertilizer treatment than in the $20 \mathrm{ml} \mathrm{L}^{-1}$ LOF or control treatments (Ridwan et al., 2020). Gracilaria sp. and Sargassum sp. LOF has the highest levels of C-Organic (1.15\%) and nitrogen $(0.67 \%)$, as well as phosphorus $(0.45 \%)$ and potassium $(0.48 \%)$ (Tsaniya et al., 2021$)$.

Although there has been a lot of research on black soybeans using solid organic fertilizers, there have been relatively few research on black soybeans using weed-based LOF. The study aimed to determine the best type of LOF, the best dose of LOF, and select the best combination of types and concentrations of LOF on the growth and yield of black soybeans.

\section{Materials and Methods}

The study took place in a plastic house in Dusun Baru, Pondok Kubang, Central Bengkulu, Bengkulu City, Indonesia, from February to June 2020. The researchers utilized a completely randomized design $(\mathrm{CRD})$ using a factorial layout. The treatment combination was repeated three times. The first factor was weed-based LOF, which consists of $\mathrm{A}_{1}$ : Siam weed (LOF-S); $\mathrm{A}_{2}$ : Goat weed (LOF-G); $A_{3}$ : Yellow creeping daisy (LOF-Y). The second factor was the concentration of weed-based LOF, consisting of $\mathrm{C}_{0}$ : water (Control treatment); $\mathrm{C}_{1}: 12 \mathrm{ml} \mathrm{L}^{-1} ; \mathrm{C}_{2}: 16 \mathrm{ml} \mathrm{L}^{-1} ; \mathrm{C}_{3}: 20$ $\mathrm{ml} \mathrm{L}-1$.

Ultisol topsoil was collected at a depth of $20 \mathrm{~cm}$ from the soil surface as the planting medium. Each polybag was filled with $10 \mathrm{~kg}$ of soil, and seeds were planted at a 3-5 $\mathrm{cm}$ depth from the soil 
surface. N, P, and K fertilizers were applied once, at planting date, as much as $50 \%$ of the recommended dose. The recommended dose of fertilizer for soybeans is urea: $50 \mathrm{~kg} / \mathrm{Ha}, \mathrm{SP}-36$ : 120 kg/Ha, KCl: 180 kg/Ha (Balai Penelitian Tanah Bogor, 2021)

LOF application was carried out through the soil surface around the plant. LOF application was carried out every week for one month (four times application) starting from 2 weeks after planting. The amount of LOF was $250 \mathrm{~mL} /$ plant with a volume of 50, 50, 50, and $100 \mathrm{~mL}$ per application, respectively. Pest, disease, and weeds were manually controlled when necessary. The soybean was harvested after 95 percent of the pods turned dried brown.

The following steps are taken to generate liquid organic fertilizer. Dissolve $20 \mathrm{~mL}$ of EM4, $2 \mathrm{~kg}$ of brown sugar with $20 \mathrm{~L}$ of water. Ten kilograms of yellow creeping daisy weed, Goat weed, and Siam weed were cut into $2 \mathrm{~cm}$ lengths. Weed pieces are placed in an $80 \mathrm{~L}$ plastic barrel that has been filled with $20 \mathrm{~L}$ of EM4 solution. The fertilizer ingredients are evenly mixed in the barrel, which is then tightly closed and stored for one month. During storage, the barrel's contents are stirred every four days. The LOF is ready for use once the mixture is not too pungent and has a yellowish color (Fahrurrozi et al, 2016).

The variables observed included pant height, branches number, fertile nodes number, pods number, number of seeds per pod, roots fresh weight, top fresh weight, and seed weight. Soil $\mathrm{pH}$, $\mathrm{N}, \mathrm{P}, \mathrm{K}$, and C-organic and the LOF's N, P, and K content were also analyzed.

The data were statistically analyzed using the Analysis of Variance (ANOVA), 5\% F test. The treatment means were separated using Duncan Multiple Range DMRT (5\%). The interaction between the type and concentration of LOF was tested with Orthogonal Polynomials.

\section{Results and Discussion}

\subsection{Effect of Liquid Organic Fertilizer Sources on the Growth and Yield of Black}

\section{Soybeans}

The type of LOF significantly affected the roots' fresh weight and the fresh shoot weight. Soybeans fertilized with LOF-Y produced more branches than those fertilized with LOF-G, as well as more roots and top fresh weight than those fertilized with LOF-S (Table 1).

Table 1. Effect of LOF types on black soybean vegetative growth

\begin{tabular}{cccccc}
\hline LOF types & $\begin{array}{c}\text { Plant height } \\
(\mathrm{cm})\end{array}$ & $\begin{array}{c}\text { Branch } \\
\text { number }\end{array}$ & $\begin{array}{c}\text { Fertile nodes } \\
\text { number }\end{array}$ & $\begin{array}{c}\text { Roots fresh } \\
\text { weight }(\mathrm{mg})\end{array}$ & $\begin{array}{c}\text { Top fresh } \\
\text { weight }(\mathrm{g})\end{array}$ \\
\hline LOF-G & 41.61 & $3.08 \mathrm{~b}$ & 16.17 & $50.00 \mathrm{ab}$ & $2.54 \mathrm{a}$ \\
LOF-S & 43.78 & $3.83 \mathrm{ab}$ & 16.50 & $30.00 \mathrm{~b}$ & $2.34 \mathrm{~b}$ \\
LOF-Y & 40.92 & $4.58 \mathrm{a}$ & 16.08 & $80.00 \mathrm{a}$ & $2.63 \mathrm{a}$ \\
\hline
\end{tabular}

Note: $\mathrm{LOF}=$ liquid organic fertilizer, $\mathrm{LOF}-\mathrm{G}=$ Goat weed LOF, $\mathrm{LOF}-\mathrm{S}=$ Siam weed LOF, $\mathrm{LOF}-\mathrm{Y}=$ Yellow creeping daisy LOF Numbers followed by the same letter in the same column are not significantly different in DMRT (5\%). 
Macro and micronutrients absorbed from the soil are temporarily stored in the roots. LOF contains macro and micronutrients, and the photosynthetic process necessitates a considerable number of macronutrients. The results of this study showed that the type of LOF influenced root fresh weight. The highest root fresh weight was obtained by LOF-Y treatment, followed by LOF$\mathrm{G}$ and LOF-S. The LOF-Y application resulted in a $166 \%$ higher root fresh weight than the LOFS treatment. Raksun (2014) reported that the application of LOF increased the root weight of soybean plants. The application of LOF increased root fresh weight, was followed by an increase in top fresh weight. The LOF-Y and LOF-G applications resulted in $12.4 \%$ and $8.5 \%$ higher top fresh weight than the LOF-S treatment (Table 1).

Table 2. Effect of LOF types on the black soybean yields

\begin{tabular}{lccc} 
LOF types & Pod number/plant & Seed number/plant & Seed weight/plant $(\mathrm{g})$ \\
\hline LOF-G & 29.25 & 47.00 & 5.57 \\
LOF-S & 33.00 & 55.75 & 5.40 \\
LOF-Y & 32.67 & 58.58 & 5.98 \\
\hline
\end{tabular}

Although LOF application had a significant effect on plant fresh weight, it had no significant effect on plant height, fertile nodes number, pods number, seeds number, and seed weight (Table 2). The results of Puspitasari and Elfarisna (2018) also show that the type of LOF does not significantly affect plant height. Table 1 shows that the number of branches fertilized with LOFY was higher than LOF-G. The results of this study are in line with those reported by Tamba et al. (2017) where the application of LOF affects the number of soybean branches. Although the number of branches was significantly different, the number of fertile nodes was not considerably different (Table 1).

The application of LOF-Y and LOF-G resulted in a higher top fresh weight than LOF-S (Table 1). Top fresh weight is an indicator of branches number of the plant. A higher number of branches will contribute to the higher the shoot weight (Amir \& Fauzy, 2018). This result might have been related to LOF macro and micronutrient content for plant growth and development. Table 3 shows the nutrient composition of each LOF examined in this study.

Table 3. The nutrient content of liquid organic fertilizer (LOF)

\begin{tabular}{lcccc}
\hline \multicolumn{1}{c}{ LOF } & $\mathrm{pH}(\mathrm{me} / 100)$ & $\mathrm{N}(\%)$ & $\mathrm{P}(\%)$ & $\mathrm{K}(\%)$ \\
\hline Siam weed & 6.76 & 0.36 & 6.80 & 0.96 \\
Yellow creeping daisy & 7.44 & 0.22 & 6.61 & 0.75 \\
Goat weed & 6.14 & 0.44 & 6.94 & 0.61 \\
\hline
\end{tabular}

The three types of fertilizers did not show a significantly different effect on the number of pods, number of seeds, and seed weight. Thus, the three types of liquid fertilizer, derived from Siam weed, yellow creeping daisy, and Goat weed, can be applied to soybean plants and produce the same number and weight of seeds. LOF has a $\mathrm{pH}$ range of 6.14 to $7.44, \mathrm{~N}$ content of 0.22 to 
$0.44 \%, \mathrm{P}=6.61$ to $6.94 \%$ t, and $\mathrm{K}=$ of 0.61 to $0.96 \%$ (Table 3). N, P, and content of LOF is highly dependent on a mixture of organic materials. According to the findings of Lesik et al. (2019), a mixture of $30 \%$ rumen fluid $+70 \%$ agricultural waste had higher $\mathrm{N}, \mathrm{P}$, and $\mathrm{K}$ content than a mixture of $15 \%$ rumen fluid $+85 \%$ agriculture waste or 45 percent rumen fluid +55 percent agriculture waste. The use of LOF also boosted rice production. A 2:1 legowo planting system and a liquid organic fertilizer made from Gliricidia leaves + banana weevil produced the highest yields per hectare (Mollah et al., 2021).

\subsection{Effect of LOF Concentration on the Growth and Yield}

The application of LOF at various concentrations had no significant effect on plant height and shoot fresh weight. However, the increase in LOF concentration tends to increase plant height and top fresh weight (Figure 1). Plant height ranged from $39.56-45.92 \mathrm{~cm}$, lower than its potential, $53.2 \mathrm{~cm}$. Thus, to enhance plant height, higher LOF concentration is necessary. LOF from vegetable waste at various concentrations did not influence the height of lettuce, as reported by Frasetya et al. (2021). However, Kasim et al. (2019) concluded, the application of LOF at a concentration of $10 \mathrm{ml} / \mathrm{L}$ increased the growth of passion fruit. Therefore, the effect of LOF depends, among others, on the source of the LOF material, concentration, target plant, environmental factors, and others.

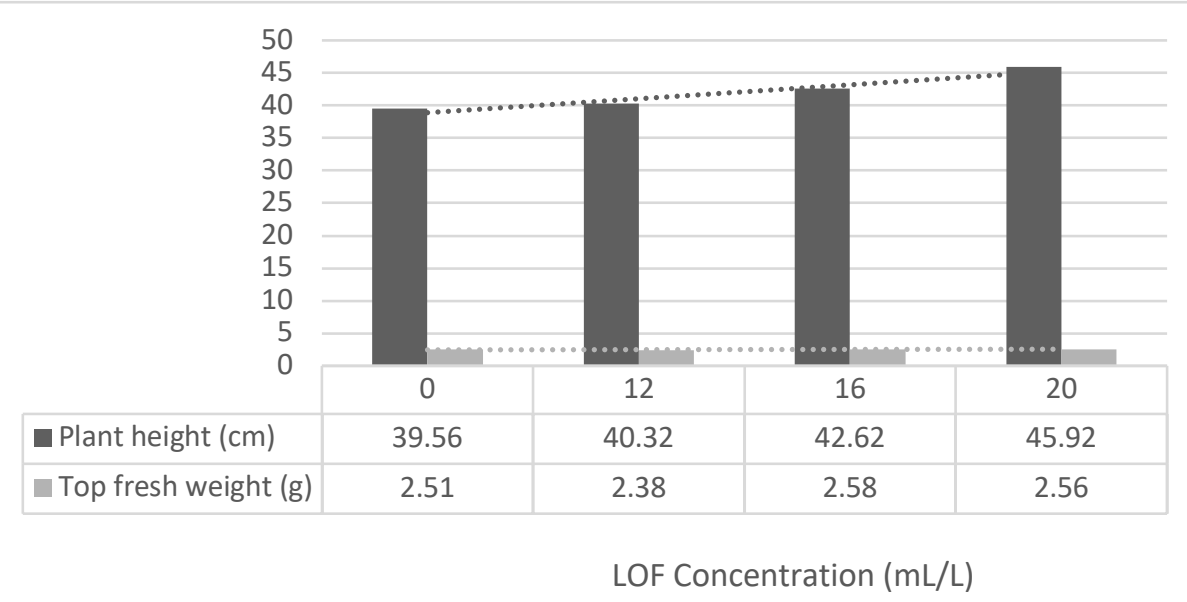

Figure 1. Effect of LOF concentration on plant height and top fresh weight

Figure 2 also illustrates that an increase in LOF concentration tends to increase the number of branches and fruitful soybean nodes, although the difference is not significant. The number of branches varied between 2.89 and 4.67, while the number of fertile nodes varied between 14.11 and 18.33 .

The performance of soybean growth was followed by the soybean yield, where LOF application did not inhibit the soybean yield components. The number of soybean seeds per plant ranged from $47.89-57.33$, while the seed weight was $4.79-6.36 \mathrm{~g} / \mathrm{plant}$, both of which showed an increasing trend with increasing LOF concentration (Figure 3). The results of Hasanah et al. 
(2021) showed that LOF at concentrations of 40,60 , and $80 \mathrm{ml} / \mathrm{L}$ had no significant effect on the growth and yield of black soybeans except for the dry weight of 100 seeds.

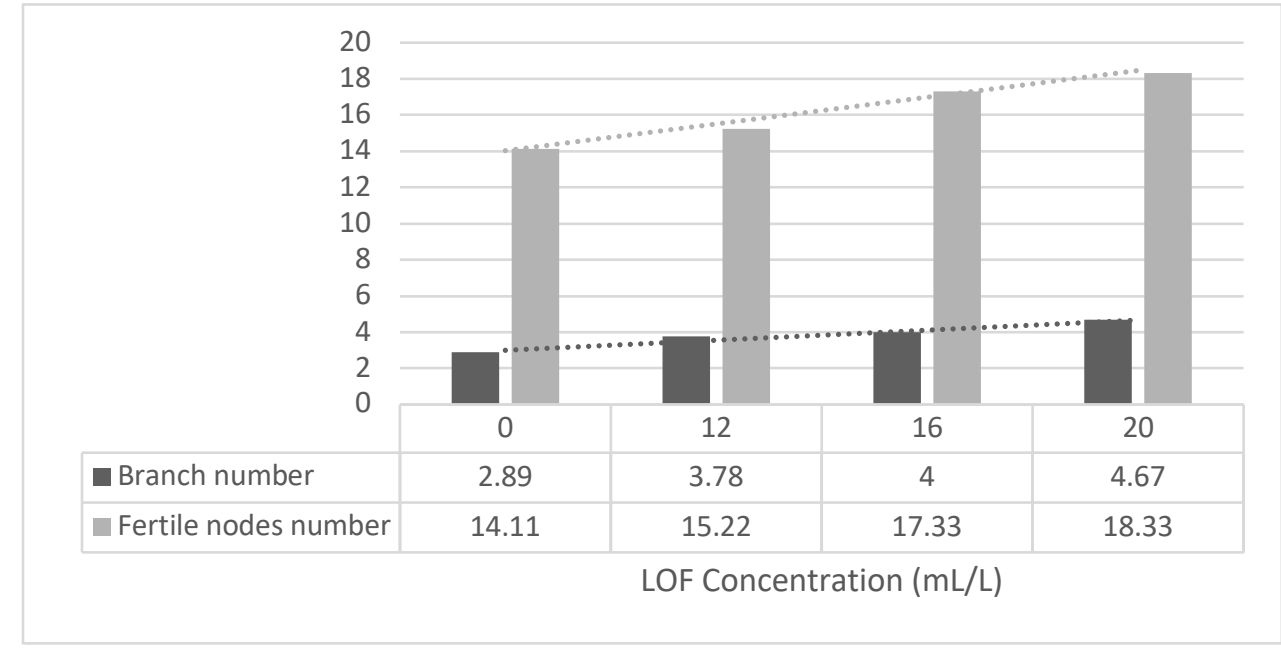

Figure 2. Effect of LOF concentration on the branch and fertile nodes number

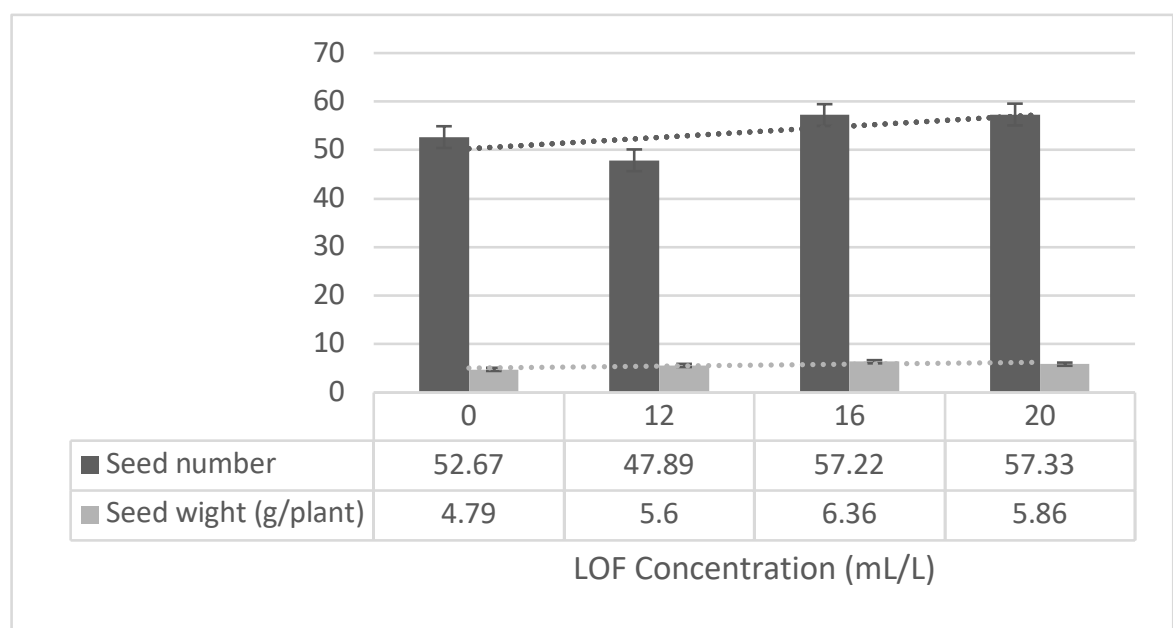

Figure 3. Effect of LOF concentration on seed number and seed weight

Nutrient requirements for plant must be achieved in order to provide its maximum growth. Lack or excess of nutrients has a negative impact on plant growth and yield. The results demonstrated that LOF was unable to meet the nutrient needs of soybean plants, resulting in lower growth and development than its potential yield. As a result, higher LOF concentration is necessary to boost soybean growth and yield.

The type of LOF and the concentration of LOF used must be adjusted to the plant nutrient requirement. Plant growth and development will not be optimum when LOF does not provide sufficient plant nutrients. The findings of this study show that the height of soybean plants is lower than the potential yield. Detam 4 is a black soybean variety with a potential plant height of 53.2 $\mathrm{cm}$, but the plant height in this study was only $45.92 \mathrm{~cm}$. In this research, the application of LOF 
was carried out through the ground. Further study can investigate the application of LOF through leaves.

According to Balai Penelitian Tanah Bogor (2021), soybean fertilization in Ultisol was 50 $\mathrm{kg} / \mathrm{Ha}, 120 \mathrm{~kg} / \mathrm{ha}, 180 \mathrm{~kg} / \mathrm{Ha}$ for urea, SP36, and KCl. Meanwhile, Permadi and Haryati (2015) reported that soybean cultivation required fertilization of are urea 25-75 kg/Ha, SP-36 50-100 $\mathrm{kg} / \mathrm{Ha}$, and $\mathrm{KCl} 50-100 \mathrm{~kg} / \mathrm{Ha}$ for the first and urea of $20 \mathrm{~kg} / \mathrm{Ha}$ for the second application. In this study, the dose of synthetic fertilizer was $50 \%$ of the recommended dose (urea $25 \mathrm{~kg} / \mathrm{Ha}$, SP-36 $60 \mathrm{~kg} / \mathrm{Ha}$, and $\mathrm{KCl} 90 \mathrm{~kg} / \mathrm{Ha}$ ). As a result, the LOF application has failed to meet the nutrient requirement of soybean plants, resulting in lower soybean yields than its potential. The $50 \%$ dose was used to see whether LOF could replace the synthetic fertilizers that were tested.

\subsection{Interaction Between LOF Concentration and Root Fresh Weight}

Liquid organic fertilizer has positive linear relationship to root fresh weight with an equation of $y=0.005 x+0.0191$ and coefficient of determination $R^{2}=+0.6523$ as indicated in Figure 4 .

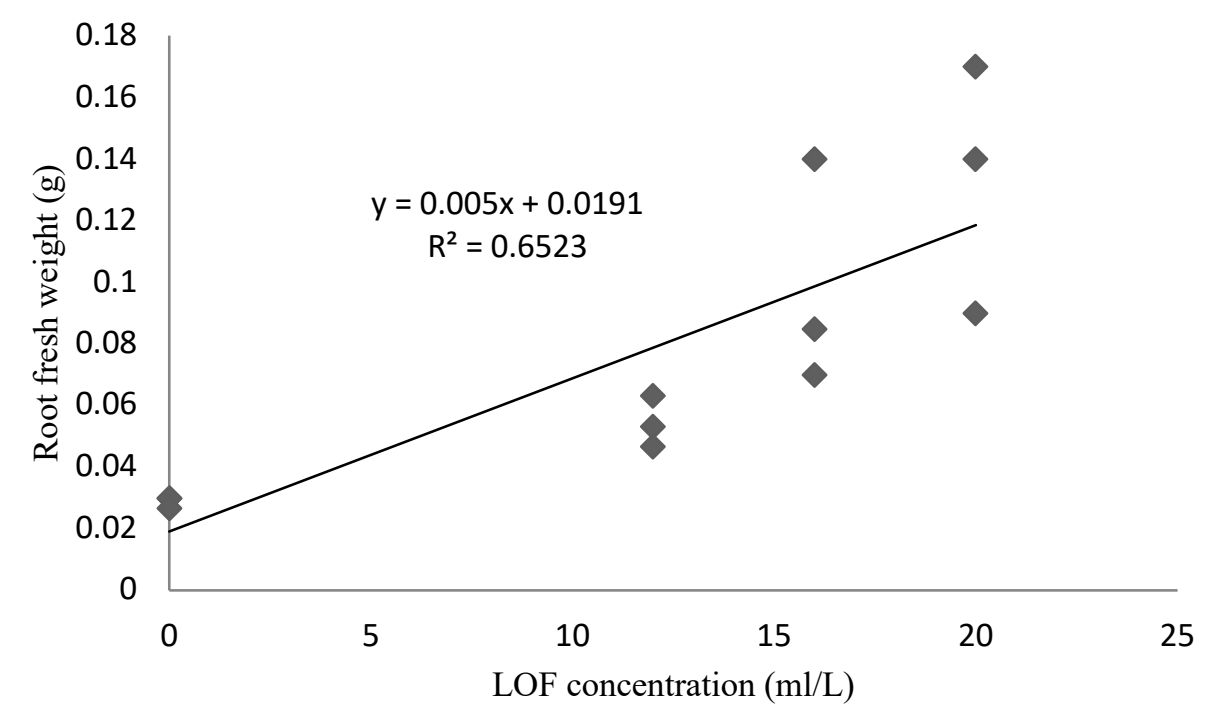

Figure 4. Relationship between the concentration of LOF and root fresh weight.

As indicated from Figure 4, increasing the dose of $4 \mathrm{ml} / \mathrm{L} \mathrm{LOF}$ will increase fresh root weight by $0.02 \mathrm{~g}$. A coeffecient Correlation of 0.65 (high) indicates that LOF has $65 \%$ contribution increase in root fresh weight. Thus, the nutrients supplying by LOF to plant roots were not evenly distributed throughout the plant. Because LOF was not disseminated to the top of the plant, it does not affect plant growth and yield. Figure 5 shows, the higher LOF concentration increases the number of pods. However, the contribution of LOF to the number of pods is very low, only $6 \%$.

The average number of pods produced in this study was 37, which was less than the 55 pods as described in Detam 4 black soybean. As a result, the number of seeds and the weight of soybean seeds was also not significantly different among LOF concentrations. 
Plant growth and yield are dependent on two factors, internal and external factors. Internal factors include genetic traits such as plant age, plant morphology, plant yield, disease resistance, and others. External factors that affect plant growth include climate, soil fertility, biotechnology, and others. LOF treatment did not affect the growth and yield of plants grown in Ultisols. The application of LOF combined with 50\% synthetic fertilizer of the recommended dose has not met the nutrient requirement for plant growth and development. Accordingly, soybean yields are lower than their potential yields.

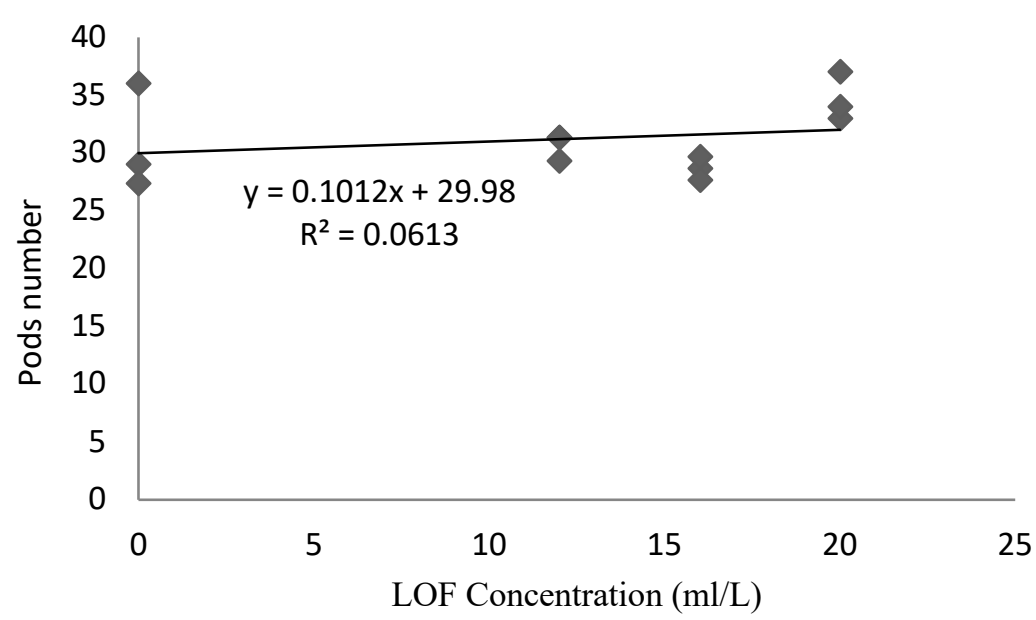

Figure 5. Relationship between POC concentration and number of pods per plant

The low yield of soybeans was also influenced by high rainfall. Rainfall ranged from 321 to $406 \mathrm{~mm} /$ month (high) at the study time, while the appropriate rainfall for soybean cultivation is within 120 and $135 \mathrm{~mm} / \mathrm{month}$ (Sumarno \& Mansyuri, 2007). High rainfall during the study apparently caused frequent water soak of the plant. Plant growth was inhibited since the absorption of nutrients by plant roots was hampered by stagnant water on the soil surface. In addition to high rainfall, soil $\mathrm{pH}$ also affects plant growth and yield. The soil has a $\mathrm{pH}$ of 4.08 , which is not suitable for soybean growth. Rahayu and Berlian (2007) stated that soil pH below 5.5 could have high aluminum saturation ins soil, leading to Al toxicity in the plant.

\section{Conclusions}

Weed-based organic fertilizer (LOF) Yellow creeping daisy produced the same plant height, node, pod, and seed number and seed weight as the application of LOF Goat weed and Siam weed. In addition, application of LOF Yellow creeping daisy resulted in a higher number of branches than LOF Goat weed and higher root and top weight than LOF Siam weed.

\section{References}

Amir, N., \& Fauzy, M. F. (2018). Pengaruh Jenis Pupuk Organik Cair Limbah Tanaman dan Takaran Pupuk Kotoran Ayam terhadap Pertumbuhan Tanaman Kedelai (Glycine max L. 
Merril). Klorofil: Jurnal Penelitian Ilmu-Ilmu Pertanian, 13(1), 17-21. Retrived from https://jurnal.um-palembang.ac.id/klorofil/article/view/1094

Balai Penelitian Tanah Bogor. (2021, July 1). Rekomendasi pemupukan Tanaman Kedelai pada Berbagai Tipe Penggunaan Lahan. Retrived from https://balittanah.litbang.pertanian.go.id/

Bete, H. (2018). Pengaruh Pemberian Pupuk Cair Daun Kirinyuh (Chromolaena odorata) terhadap Pertumbuhan Tanaman Bayam Merah (Amaranthus tricolor L.) (Thesis). Retrived from https://repository.usd.ac.id/18472/2/131434067_full.pdf

Duaja, M. D. (2012). Pengaruh Bahan dan Dosis Kompos Cair terhadap Pertumbuhan Selada (Lactuca sativa sp.). Jurnal Bioplantae, 1(1), 14-22. Retrived from https://onlinejournal.unja.ac.id/bioplante/article/view/1738

Fahrurrozi, F., Muktamar, Z., Dwatmadji, D., Setyowati, N., Sudjatmiko, S. \& Chozin, M. (2016). Growth and Yield Responses of Three Sweet-Corn (Zea mays L. var. Saccharata) Varieties to Local-based Liquid Organic Fertilizer. International Journal on Advanced Science $\begin{array}{lllll}\text { Engineering Information } & \text { Technology, } & 6 & \text { (3), }\end{array}$ https://doi.org/10.18517/ijaseit.6.3.730

Frasetya, B., Taofik, A., \& Nasrulloh, L. (2021, March). The effectiveness of the application method of liquid organic fertilizer in different concentration on lettuce. In IOP Conference Series: Earth and Environmental Science (Vol. 694, No. 1, p. 012024). IOP Publishing. https://doi.org/10.1088/1755-1315/694/1/012024

Hasanah, Y., Lahay, R. R., \& Pangestu, W. (2021, June). Response of edamame growth and production in the lowlands by spacing treatment and application of liquid organic fertilizers. In IOP Conference Series: Earth and Environmental Science (Vol. 782, No. 4, p. 042025). IOP Publishing. https://doi.org/10.1088/1755-1315/782/4/042025

Kasim, N., Amin, R., Mariyati, T., \& Nurvitasari, E. (2019, October). Growth of passion fruit plants on various origins of cuttings and concentration of Liquid Organic Fertilizer. In IOP Conference Series: Earth and Environmental Science (Vol. 343, No. 1, p. 012029). IOP Publishing. https://doi.org/10.1088/1755-1315/343/1/012029

Kilkoda, A. K., Nurmala, T. \& Widayat, D. (2015). Pengaruh Keberadaan Gulma (Ageratum conyzoides dan Boreria alata) terhadap Pertumbuhan dan Hasil Tiga Ukuran Varietas Kedelai (Glycine max L. Merril) pada Percobaan Pot Bertingkat. Jurnal Kultivasi, 14(2), 19. https://doi.org/10.24198/kultivasi.v14i2.12072

Lesik, M. M. N. N., Dadi, O., Andira, G., \& Laban, S. (2019, October). Nutrient analysis of liquid organic fertilizer from agricultural waste and rumen liquid. In IOP Conference Series: Earth and Environmental Science (Vol. 343, No. 1, p. 012178). IOP Publishing. https://doi.org/10.1088/1755-1315/343/1/012178

Nasira, W., Adawiyah, R., Sadimantara, G. R., \& Yusuf, D. N. (2021, July). Effect of liquid organic fertilizer derived from moringa on growth of upland red rice lines crosses from SE Sulawesi. In IOP Conference Series: Earth and Environmental Science (Vol. 807, No. 4, p. 042037). IOP Publishing. https://doi.org/10.1088/1755-1315/807/4/042037

Permadi, K., \& Haryati, Y. (2015). Pemberian Pupuk N, P, dan K Berdasarkan Pengelolaan Hara Spesifik Lokasi untuk Meningkatkan Produktivitas Kedelai. Agrotrop: Journal on Agriculture Science, 5(1), 1-8.

Puspitasari, A., \& Elfarisna, E. (2018). Respon Pertumbuhan dan Produksi Kedelai Varietas Grobogan dengan Penambahan Pupuk Organik Cair dan Pengurangan Dosis Pupuk Anorganik. Prosiding SEMNASTAN, 204-212. Retrived from https://jurnal.umj.ac.id/index.php/semnastan/article/view/2276

Puteri, A. R., Setyowati, N., \& Muktamar, Z. (2021). Growth and yield of sweet corn (Zea mays L. Saccharata) as affected by incubation time of preparation for tithonia (Tithonia diversifolia) enriched liquid organic fertilizer. In IOP Conference Series: Earth and Environmental Science (Vol. 637, No. 1, p. 012090). IOP Publishing. https://doi.org/10.1088/1755-1315/637/1/012090 
Raksun, A. (2014). Aplikasi Pupuk Organik Cair untuk Meningkatkan Pertumbuhan Kedelai (Glycine Max L.). Jurnal Biologi Tropis, 14(1), 62-67. Retrived from https://www.jurnalfkip.unram.ac.id/index.php/JBT/article/view/359

Rahayu, E. \& Berlian N. V. A. (2007). Kedelai. Jakarta, Indonesi: Penebar Swadaya.

Ridwan, I., Musa, Y., Khadijah, S., Farid, M., Sjahril, R., \& Ulfa, F. (2020, April). Response of Soybean (Glycine max L.) to Arbuscular Mycorrhizal Fungi (AMF) applied with organic liquid fertilizer. In IOP Conference Series: Earth and Environmental Science (Vol. 486, No. 1, p. 012114). IOP Publishing. https://doi.org/10.1088/1755-1315/486/1/012114

Mollah, A., Risal, M., Musa, Y., Yassi, A., \& Dachlan, A. (2021, July). Growth and production of paddy rice (Oryza sativa L.) in various planting systems and types of liquid organic fertilizers. In IOP Conference Series: Earth and Environmental Science (Vol. 807, No. 4, p. 042055). IOP Publishing. https://doi.org/10.1088/1755-1315/807/4/042055

Tsaniya, A. R., Dewi, E. N., \& Anggo, A. D. (2021, July). Characteristics of liquid organic fertilizer from different composition types of seaweed between Gracilaria sp. and Sargassum sp. In Journal of Physics: Conference Series (Vol. 1943, No. 1, p. 012071). IOP Publishing. https://doi.org/10.1088/1742-6596/1943/1/012071

Setyowati, N., Nurjanah, U. \& Haryanti, D. (2008). Gulma Tusuk Konde (Wedelia trilobata)

dan Kirinyu (Chlomolaena odorata) Sebagai Pupuk Organik pada Sawi (Brassica chinensis L.). Jurnal Akta Agrosia, 11(1), 47-56.

Setyowati, N., Nurjanah, U. \& Korisma, R. (2009). Korelasi Antara Sifat-Sifat Tanah dengan Hasil Cabai Merah pada Substitusi Pupuk N-Anorganik dengan Bokasi Tusuk Konde (Wedelia trilobata L.). Jurnal Akta Agrosia, 12(2), 134-194. Retrived from http://repository.unib.ac.id/186/

Sujana, I. P \& Pura, I. N. L. S. (2015). Pengelolaan Tanah Ultisol dengan Pemberian Pembenah Organik Biochar Menuju Pertanian Berkelanjutan. Jurnal Agrimeta, 5(9), 01-69. Retrived from https://media.neliti.com/media/publications/89640-ID-pengelolaan-tanah-ultisoldengan-pemberi.pdf

Sumarno \& Mansyuri, G. (2007). Persyaratan Tumbuh dan Wilayah Produksi Kedelai di Indonesia. Dalam Sumarno, Suyamto, Widjono, A., Hermanto \& Kasim, H. (eds). Kedelai: Teknik Produksi dan Pengembangan. Bogor, Indonesia: Pusat Penelitian dan Pengembangan Tanaman Pangan

Tamba, A., Irmansyah, T. \& Hasanah, Y. (2017). Respons Pertumbuhan dan Produksi Kedelai (Glycine max (L.) Merill) terhadap Aplikasi Pupuk Kandang Sapi dan Pupuk Organik Cair. Jurnal Agroekoteknologi USU. 5(2), 307-314. Retrived from https://talenta.usu.ac.id/joa/article/view/2549 